\title{
Influence of biotic and abiotic sediment factors on abundance and biomass of harpacticoid copepods in a shallow Antarctic bay*
}

\author{
GRITTA VEIT-KÖHLER \\ AG Zoosystematik und Morphologie, Institut für Biologie und Umweltwissenschaften, Fakultät 5, Carl-von-Ossietzky \\ Universität, D - 26111 Oldenburg, Germany. \\ Present address: Forschungsinstitut Senckenberg, DZMB Deutsches Zentrum für Marine Biodiversitätsforschung, \\ Südstrand 44, D - 26382 Wilhelmshaven, Germany. E-mail: gveit-koehler@ senckenberg.de
}

\begin{abstract}
SUMMARY: This study presents data of the first investigation on benthic harpacticoid copepods in Potter Cove, King George Island, Antarctica $\left(62^{\circ} 14^{\prime} \mathrm{S}, 58^{\circ} 40^{\prime} \mathrm{W}\right)$ with special emphasis on spatial distribution and relation to environmental factors. In addition to the individual numbers that are normally given, the biovolume of the meiobenthic copepods was measured. It showed great variety due to changes in abundance and habitat preferences of the different species along the two studied transects in the inner cove and at the cove entrance. The distribution of the two species Pseudotachidius jubanyensis and Scottopsyllus (S.) praecipuus was studied in detail; their body volumes are given for developmental stages and adults, and their importance for the total biovolume at the different stations is discussed. Statistical analyses (Spearman rank, canonical correspondence analysis) indicate that the biovolume of harpacticoid copepods was related more to total organic matter than to the carbon:nitrogen ratio and chloroplastic equivalents or even grain size and depth. While P. jubanyensis was strongly connected to depth and to a lesser extent to small grain sizes, $S$. (S.) praecipuus showed a preference for sites with low chloroplastic equivalent values, but neither of them was related to total organic matter.
\end{abstract}

Keywords: meiofauna, Copepoda, size classes, biovolume, Pseudotachidius jubanyensis, Scottopsyllus (S.) praecipuus, King George Island, Antarctic.

RESUMEN: INFLUENCIA DE LOS FACTORES BIÓTICOS Y ABIÓTICOS SOBRE LA ABUNDANCIA Y BIOMASA DE COPÉPODOS HARPACTICÓ́DEOS EN UNA CALA POCO PROFUNDA DE LA ANTÁRTIDA. - El presente estudio facilita los primeros datos sobre la distribución espacial de los copépodos harpacticoídeos bentónicos en la Caleta Potter, Isla Rey Jorge, Antártida $\left(62^{\circ} 14\right.$ 'S $58^{\circ} 40^{\prime} \mathrm{W}$ ) y su relación con factores ambientales. Además del cálculo de abundancias se midió el biovolumen de los copépodos del meiobentos. Se detectó una variabilidad bastante elevada del biovolumen debido a las diferentes preferencias ecológicas de las especies a lo largo de los dos transectos muestreados, uno en la entrada de la cala y otro en su interior. La distribución de dos de las espécies encontradas, Pseudotachidius jubanyensis y Scottopsyllus (S.) praecipuus, fué estudiada en detalle. Se presentan datos del biovolumen de los diferentes estadios ontogenéticos y de los adultos de estas dos especies y se discute su importancia para el biovolumen total en las diferentes estaciones muestreadas. Análisis estadísticos (Spearman rank, análisis canónico de correspondencias) indican que el biovolumen de los copépodos harpacticoídeos está mejor correlacionado con el contenido orgánico total que con la relación carbono:nitrógeno y equivalentes de pigmentos cloroplásticos $\mathrm{o}$ incluso con parámetros granulométricos y profundidad. $P$. jubanyensis parece estar relacionado con la profundidad $\mathrm{y}$, en menor medida, con sedimento de grano fino, mientras que $S$. (S.) praecipuus mostró preferencia por estaciónes con valores bajos de equivalentes de pigmentos cloroplásticos, pero ninguna de las especies está relacionada con el contenido total de materia orgánica.

Palabras clave: meiofauna, copépodos, clases de tamaño, biovolumen, Pseudotachidius jubanyensis, Scottopsyllus (S.) praecipuus, Isla Rey Jorge, Antártida. 


\section{INTRODUCTION}

Antarctic and Subantarctic shallow water meiofauna has been studied for many years and quite a few data sets and environmental details have been compiled. Studies normally focus on major meiofauna taxa such as nematodes, copepods, kinorhynchs and annelids and do not differentiate at species level (de Bovée and Soyer, 1977; Soyer and de Bovée, 1977; de Skowronski and Corbisier, 2002). This is partly due to the goals that have been set, such as the determination of meiofauna densities or the understanding of the relations between sediment structures and food availability on the one hand and meiofauna communities on the other (Bouvy and Soyer, 1989; de Skowronski and Corbisier, 2002). In these studies terms such as "meiofauna community structure" or "taxonomic diversity" are normally used to explain the interrelationships of individual numbers of higher taxa in a seasonal or regional context. Only recently, studies by Lee et al. (2001) and Vanhove et al. $(1998 ; 2000)$ have given detailed information, in addition to the usual meiofauna data, on the genus- or species-level taxonomic structure of the most abundant meiofauna taxon, the nematodes.

The lack of ecological species-level studies for harpacticoid copepods in the Antarctic may be due to the lack of taxonomic descriptions of animals from these latitudes. A comparison of species numbers of known Harpacticoida from the Arctic and the Antarctic clearly shows the problem we are facing in the Antarctic: for the northern polar region about four times as many species of harpacticoids are described as for the Antarctic (Wells, 1986). Obviously, there is still a lot of taxonomic work to be done for the Antarctic.

This work presents a study on benthic harpacticoids from Potter Cove, King George Island, Antarctic. Although still far from the final aim of describing an Antarctic benthic copepod assemblage at species level, it gives additional accessible information on top of the mere comparison of individual numbers: the biovolume of benthic copepods. The biovolume of a meiofauna fraction can give important information on the suitability of a habitat for a certain taxon, or the habitat preferences of certain biotypes. For this study, the idea of taking the biovolume of the benthic copepods into account arose in order to investigate whether body size in Antarctic meiofauna was an additional means of differentiating between distinct sampling stations. Together with descriptions of new harpacticoid species from Potter Cove, this study should contribute to both the taxonomical and ecological investigation of the meiofauna of the Antarctic.

\section{MATERIAL AND METHODS}

\section{Study site and sampling}

This study was carried out in Potter Cove (62 ${ }^{\circ} 14^{\prime}$ S, 58 $40^{\prime}$ W) (Fig. 1), Maxwell Bay, on King George Island, South Shetland Islands, Antarctic where the German Dallmann Laboratory is located as an annex to the Argentinian Jubany Station. Klöser and Arntz (1994) gave a detailed description of the site. Two depth transects $(5,10,20$ and $30 \mathrm{~m})$ were sampled during the Antarctic summer (02/01/1996 - 09/02/1996). The inner cove Transect 1 (perpendicular to the former Casa Bomba) is an unexposed area protected by a shallow ridge at its entrance. On Transect 1 muddy sediments predominate. The deeper sampling stations of this site are not affected by strong currents or disturbed by icebergs as frequently as on Transect 2 . The latter (perpendicular to Punta Elefante) is located at the ridge between inner and outer cove, which - with a maximum depth of about $30 \mathrm{~m}$-constitutes a natural barrier for big icebergs. Therefore, it is an exposed area with slightly sandier sediments at least at the uppermost stations. Strong near-bottom currents are always present.

Meiofauna samples were collected by scuba diving $(01 / 02 / 1996$ to $09 / 02 / 1996)$ along the two depth

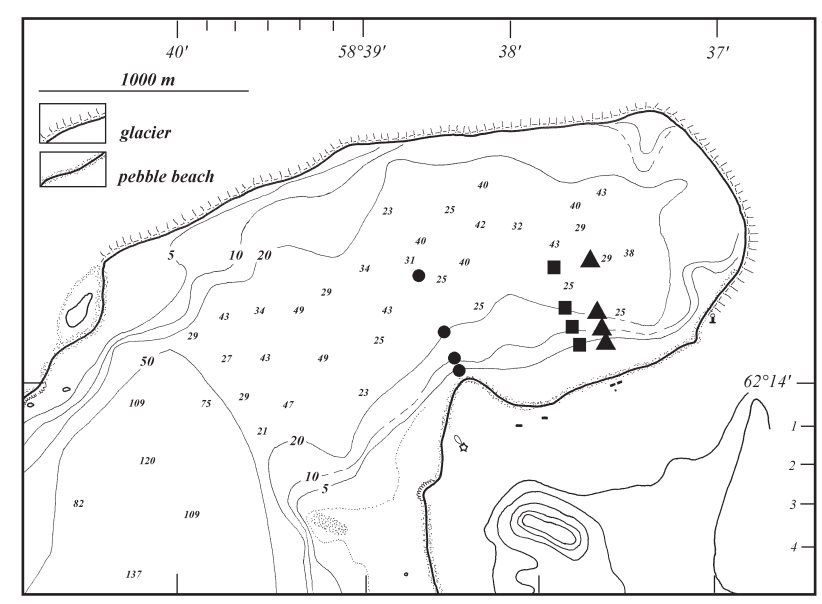

FIG. 1. - Map of Potter Cove, King George Island, Antarctic with bathymetric contours, additional single depths (modified after: Atlas Hidrografico, Chile) and transect locations. Black triangles: Transect 1 , inner cove; black dots: Transect 2 , cove entrance; black squares: transect sampled by Mayer (2000). 
transects. At each station six sediment corers of 80 $\mathrm{cm}^{2}$ each were randomly pushed into the sediment and brought to the surface as undisturbed as possible. The upper $3 \mathrm{~cm}$ of oxidised sediment layer of three sediment cores were split into four equal parts each and frozen for biochemical and grain size analysis (even the samples from stations with muddy sediment were deeply oxidised-no black reduced layer visible-because the sediment was very fluid). The resulting 12 parts provided 3 true replicate samples for each sediment analysis. The upper $3 \mathrm{~cm}$ sediment layer of the remaining three sediment cores was preserved in $5 \%$ formalin.

Abbreviations used in the text:

Stations: Transect $1,30 \mathrm{~m}=1.30$;

Transect 2, $5 \mathrm{~m}=2.05$

Individuals per $10 \mathrm{~cm}^{2}=$ Ind. $10 \mathrm{~cm}^{-2}$

\section{Sediment analyses}

Grain size analysis was conducted with freezedried sediment samples for the inorganic sediment components. After a treatment with $\mathrm{H}_{2} \mathrm{O}_{2}$ and $\mathrm{HCl}$ to destroy organic matter and calcareous particles, the sediment was wet-sieved through a series of 2000 , 630, 200, 63 and $20 \mu \mathrm{m}$ meshes. The fine silt $(<20$ $\mu \mathrm{m})$ and clay $(<2 \mu \mathrm{m})$ fractions were determined by drying the rinsing water. The mean diameter $\Phi$ $(\mathrm{Md})$, the inclusive graphic quartile deviation (QDI) and the inclusive graphic skewness (SkI) were determined graphically and calculated according to Folk (1974). Mean grain size was calculated from the mean diameter $\Phi$ after Giere et al. (1988).

The total organic matter (TOM) represented by the ash-free dry weight of the freeze-dried and homogenised sediment was determined by combustion at $500^{\circ} \mathrm{C}$ for four hours in a muffle furnace. Contents of organic carbon and nitrogen were measured from freeze dried, homogenised and HCl-treated sediment using a Fison $\mathrm{C} / \mathrm{N}$ analyser and expressed as molar $\mathrm{C} / \mathrm{N}$. Chloroplastic pigments were extracted with acetone (90\%) from defrosted homogenised sediment samples. Extinctions were measured photometrically (Shimadzu UV-1202) and chloroplastic equivalents (CPE), represented by the sum of chlorophyll $a$ and phaeopigments, were calculated using the equations given by Greiser and Faubel (1988).

\section{Meiofauna treatment}

The fixed samples were washed using a $40 \mu \mathrm{m}$ mesh sieve with tap water. Meiofauna and organic material were extracted from the remaining sand particles by centrifugation with a colloidal silica polymer (Ludox) as the flotation medium and kaolin to cover the heavier particles (McIntyre and Warwick, 1984). The centrifugation was repeated three times at $5000 \mathrm{rpm}$ for five minutes each. After each centrifugation the floating matter was decanted and rinsed with tap water. This supernatant normally contains all organic material found in the sample. In this special case masses of particles of macroalgal detritus made sorting of the whole samples unrealistic and it was decided to split the samples in order to get manageable sample sizes.

Two centrifuged cores per sampling station were chosen. A meiofauna sample splitter after Jensen (1982) was used to obtain eight equal parts of each sample. The sample was filled up with tap water to a defined level and after splitting only equally divided samples were accepted, with the volume of all eight parts being the same. In order to ensure this, marks for the correct subsample volume were drawn on the outside of the transparent splitting chambers. When the splitting did not fulfil the prerequisites, the subsamples were unified again and the procedure was repeated. Finally, three subsamples per core were randomly selected and sorted. In total 6 parts representing altogether $60 \mathrm{~cm}^{2}$ of sediment surface were investigated per station. Sample parts were stained with rose bengal for sorting and copepods were subsequently transferred to glycerine-lactate for clearing. The individual numbers were counted and the median values taken for further interpretation.

Body length and maximum width of 87 specimens of Pseudotachidius jubanyensis Veit-Köhler and Willen, 1999, 74 specimens of Scottopsyllus (Scottopsyllus) praecipuus Veit-Köhler, 2000 and 534 other harpacticoid copepods (adults and copepodid stages) were measured with the aid of a camera lucida. Per depth station on each transect, 100 other harpacticoids were randomly selected. When a station did not yield 100 specimens, all available animals were taken into account (Transect $1=223$ specimens; Transect $2=311$ specimens).

Body volumes were calculated using the body shape-dependent conversion factors $\mathrm{C}$ given by Warwick and Gee (1984):

Body volume $[\mathrm{nl}]=$ length $[\mathrm{mm}] \times(\text { width }[\mathrm{mm}])^{2} \times \mathrm{C}$

Biovolume was calculated using the stationdependent mean value of body volume per copepod 
and the median values of individual numbers per station. For the two distinctly larger species $P$. jubanyensis and $S$. (S.) praecipuus, sex- and developmental stage-dependent body volumes were calculated and considered according to abundance and distribution of sexes and stages in the samples.

\section{Statistical analysis}

For all variables of the different stations median rather than average values were used. This procedure was chosen because the calculation of mean values assumes the existence of a normal distribution of the data. Additionally, replicative sampling is required, which due to the necessary splitting of meiofauna samples was not given for this part of the study. Furthermore, outliers disproportionately influence mean values when applied to lower sample numbers.

With a Spearman rank test the correlations between individual numbers and biovolumes on the one hand and the environmental data on the other hand were tested. The Spearman rank was chosen because it can be applied to small data sets and even when the data are not distributed normally. To relate total harpacticoids and harpactiocid biovolume to grain size, TOM, C/N and CPE, the coefficient $r_{S}$ was calculated. For the distributions and biovolumes of $P$. jubanyensis and $S$. (S.) praecipuus, as well as for all relations to water depth, the coefficient $r_{S, B}$ had to be used, as the coefficient $r_{S}$ would have overestimated the correlations due to the occurrence of similar ranks in these data sets (Sachs, 1974).

For data interpretation a canonical correspondence analysis (CCA) was chosen, as this analysis allows animal data and environmental data to be compared at different sample sites at the same time.
CCA was carried out after Ter Braak (1986), using the statistical package MVSP 3.1. No data transformations were carried out, as every transformation bears the risk of bias.

\section{RESULTS}

\section{Sediment analyses}

On both transects grain size of the upper $3 \mathrm{~cm}$ sediment layer shows a clear tendency towards smaller fractions with depth. While Transect 1 in the inner cove is characterised by the dominating silt and clay fraction $(43.4 \%$ at $5 \mathrm{~m} ; 80 \%$ at $30 \mathrm{~m})$, Transect 2 at the cove entrance reveals a higher amount of fine sand $(57.4 \%$ at $5 \mathrm{~m} ; 49 \%$ at $20 \mathrm{~m}$ ), which is exceeded by the silt and clay fraction at 2.30 of $58 \%$. The data for the mean grain size as determined graphically and calculated from Md support these findings (Table 1). The apparent discrepancies between dominating sediment fraction and mean grain size are due to the very heterogeneous grain size distributions along both transects, as indicated by the very high QDI between 1.98 and 3.27, which stands for poorly to very poorly sorted sediments. The SkI values show that 1.05 has a symmetric grain size distribution. For the other stations negative SkI values indicate a displacement of $\mathrm{Md}$ and a preponderance of fine sediments. In contrast, at the three upper stations on Transect 2 positive SkI values show that, despite the relatively low Md, the coarser fractions prevail. Only at 2.30 are the sediment fractions symmetrically distributed.

TOM normally ranges between 4.40 and $5.48 \%$ for the upper $3 \mathrm{~cm}$ sediment layer along the two transects. Only 2.10 shows differing values: the

TABLE 1. - Median values of mean grain size, inclusive graphic quartile deviation (QDI), inclusive graphic skewness (SkI), total organic matter (TOM), molar carbon:nitrogen ratio $(\mathrm{C} / \mathrm{N})$, and chloroplastic equivalents $(\mathrm{CPE})$ along Transect 1 in the centre of and Transect 2 at the entrance to Potter Cove; ${ }^{1}=5 \mathrm{~m}$ station of Transect 1 omitted from statistical analysis.

\begin{tabular}{|c|c|c|c|c|c|c|}
\hline $\begin{array}{l}\text { Station and depth } \\
{[\mathrm{m}]}\end{array}$ & $\begin{array}{l}\text { Mean grain size } \\
{[\mu \mathrm{m}]}\end{array}$ & QDI & SkI & $\begin{array}{c}\text { TOM } \\
{[\% \mathrm{dw}]}\end{array}$ & $\begin{array}{l}\mathrm{C} / \mathrm{N} \\
\text { molar }\end{array}$ & $\begin{array}{c}\mathrm{CPE} \\
{\left[\mu \mathrm{g}\left(\mathrm{g}^{-1} \mathrm{dw}\right)\right]}\end{array}$ \\
\hline \multicolumn{7}{|c|}{ Transect 1 Inner cove } \\
\hline $5^{1}$ & 27 & 3.27 & -0.05 & 5.13 & 6.63 & 14.15 \\
\hline 10 & 12 & 2.75 & -0.3 & 5.23 & 7.20 & 3.96 \\
\hline 20 & 11 & 2.42 & -0.2 & 4.79 & 6.42 & 2.57 \\
\hline 30 & 7 & 1.98 & -0.16 & 5.48 & 6.52 & 3.25 \\
\hline \multicolumn{7}{|c|}{ Transect 2 Cove entrance } \\
\hline 5 & 40 & 2.32 & 0.16 & 4.40 & 7.23 & 7.84 \\
\hline 10 & 22 & 2.47 & 0.22 & 6.15 & 8.36 & 20.60 \\
\hline 20 & 32 & 2.4 & 0.56 & 5.13 & 7.99 & 9.94 \\
\hline 30 & 15 & 2.5 & -0.06 & 5.40 & 8.07 & 5.77 \\
\hline
\end{tabular}


TABLE 2. - Median values of individual numbers and biovolumes of other Harpacticoida, Scottopsyllus (S.) praecipuus, and Pseudotachidius jubanyensis (biovolume weighed for developmental stages) along Transect 1 in the centre of and Transect 2 at the entrance to Potter Cove;

$1=5 \mathrm{~m}$ station of transect 1 omitted from statistical analysis.

\begin{tabular}{|c|c|c|c|c|c|c|}
\hline $\begin{array}{l}\text { Station and } \\
\text { depth }[\mathrm{m}]\end{array}$ & $\begin{array}{l}\text { Other Harpacticoids } \\
\text { [Ind. } 10 \mathrm{~cm}^{-2} \text { ] }\end{array}$ & $\begin{array}{l}\text { S. (S.) praecipuus } \\
\text { [Ind. } 10 \mathrm{~cm}^{-2} \text { ] }\end{array}$ & $\begin{array}{l}P . \text { jubanyensis } \\
{\left[\text { Ind. } 10 \mathrm{~cm}^{-2} \text { ] }\right.}\end{array}$ & $\begin{array}{l}\text { Other Harpacticoids } \\
\qquad\left[\mathrm{nl} 10 \mathrm{~cm}^{-2}\right]\end{array}$ & $\begin{array}{c}\text { S. (S.) praecipuus } \\
{\left[\mathrm{nl} 10 \mathrm{~cm}^{-2}\right]}\end{array}$ & $\begin{array}{c}P . \text { jubanyensis } \\
{\left[\mathrm{nl} 10 \mathrm{~cm}^{-2}\right]}\end{array}$ \\
\hline \multicolumn{7}{|c|}{ Transect 1 Inner cove } \\
\hline $5^{1}$ & 3 & 0 & 0 & 33.6 & 0 & 0 \\
\hline 10 & 5 & 0 & 0 & 24.0 & 0 & 0 \\
\hline 20 & 32 & 8 & 2 & 118.4 & 74.6 & 16.6 \\
\hline 30 & 66 & 2 & 10 & 237.6 & 5.4 & 340.5 \\
\hline \multicolumn{7}{|c|}{ Transect 2 Cove entrance } \\
\hline 5 & 21 & 0 & 0 & 105.0 & 0 & 0 \\
\hline 10 & 216 & 0 & 0 & 648.0 & 0 & 0 \\
\hline 20 & 92 & 0 & 0 & 285.2 & 0 & 0 \\
\hline 30 & 64 & 2 & 2 & 192.0 & 24.8 & 81.4 \\
\hline
\end{tabular}

$6.15 \%$ concentration of organic matter is higher than that of all other stations. This is due to the accumulation of macroalgal detritus in a depression at the sampling site (pers. observation).

$\mathrm{C} / \mathrm{N}$ for the upper $3 \mathrm{~cm}$ sediment layer varies between 6.42 and 8.36. The values on the detritusrich Transect 2 are higher than on Transect 1, supporting the visual findings: while sediments on Transect 1 were covered with living benthic diatoms, thus revealing comparatively more nitrogen, Transect 2 is characterised by higher amounts of dead organic material, especially macroalgal detritus originating from the kelp at the rocky sites of the bay.

CPE as the sum of chlorophyll $a$ and phaeopigments in the upper $3 \mathrm{~cm}$ sediment layer clearly follows the findings of the other biotic sediment factors: higher amounts along Transect 2 are due to macroalgal detritus particles, especially at 2.10 with $20.60 \mu \mathrm{g} / \mathrm{g} \mathrm{dw}$. The high values at the $5 \mathrm{~m}$ station of Transect 1 are the effect of cyanobacteria mats (pers. observation), which emerged as a consequence of the nearby station drainage. As this situation differed greatly in its conditions from the other sites, 1.05 was excluded from further statistical analysis.

\section{Copepod abundances and biovolume}

Benthic copepods in the central Potter Cove show increasing abundances with depth (Table 2). Along Transect 1 median individual densities for the upper $3 \mathrm{~cm}$ sediment layer reach their maximum with altogether 78 Ind. $10 \mathrm{~cm}^{-2}$ at $30 \mathrm{~m}$ depth. On Transect 2 at the entrance to the inner cove, the highest copepod abundance overall is recorded from the $10 \mathrm{~m}$ station with 216 Ind. $10 \mathrm{~cm}^{-2}$. A marked decrease in individual densities for the deeper sta-
TABLE 3. - Geometrical size classes applied to the body volumes of benthic copepods sampled along two depth transects in the centre of and at the entrance to Potter Cove.

\begin{tabular}{cc}
\hline Geometrical size class & Biovolume $[\mathrm{nl}]$ \\
\hline 1 & $0.2-0.39$ \\
2 & $0.4-0.79$ \\
3 & $0.8-1.59$ \\
4 & $1.6-3.19$ \\
5 & $3.2-6.39$ \\
6 & $6.4-12.79$ \\
8 & $12.8-25.59$ \\
9 & $25.6-51.19$ \\
& $51.2-102.4$ \\
\hline
\end{tabular}

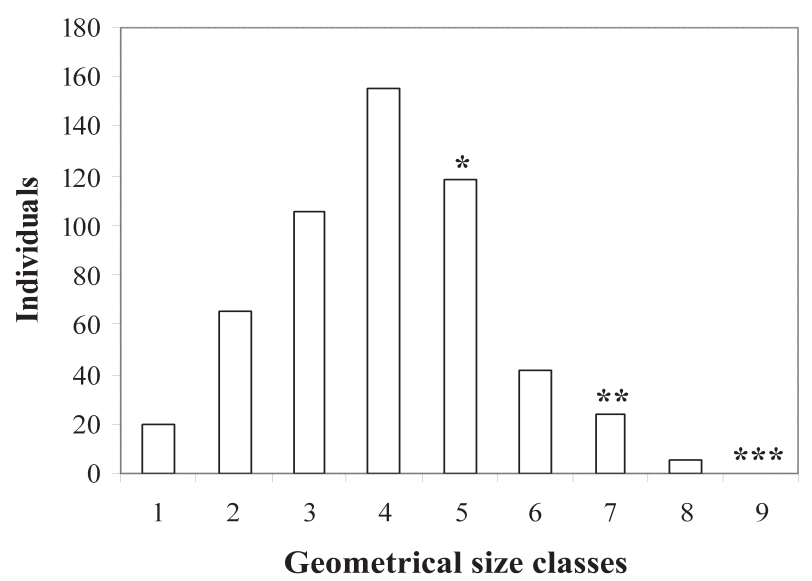

FIG. 2. - Distribution of 534 randomly selected "other" benthic harpacticoids from Potter Cove according to geometrical size classes based on body volumes (Table 3 ). Examples for size classes in which developmental stages of $S$. (S.) praecipuus and $P$. jubanyensis should be placed: * = C I P. jubanensis; $* *=\mathrm{C}$ VI F S. (S.) praecipuus; *** = C VI F P. jubanyensis.

tions was observed, although the $30 \mathrm{~m}$ station revealed approximately the same numbers as the deepest station of the inner cove transect.

Biovolume of benthic copepods was calculated by multiplying the station-dependent mean body volume by the median individual number per sta- 


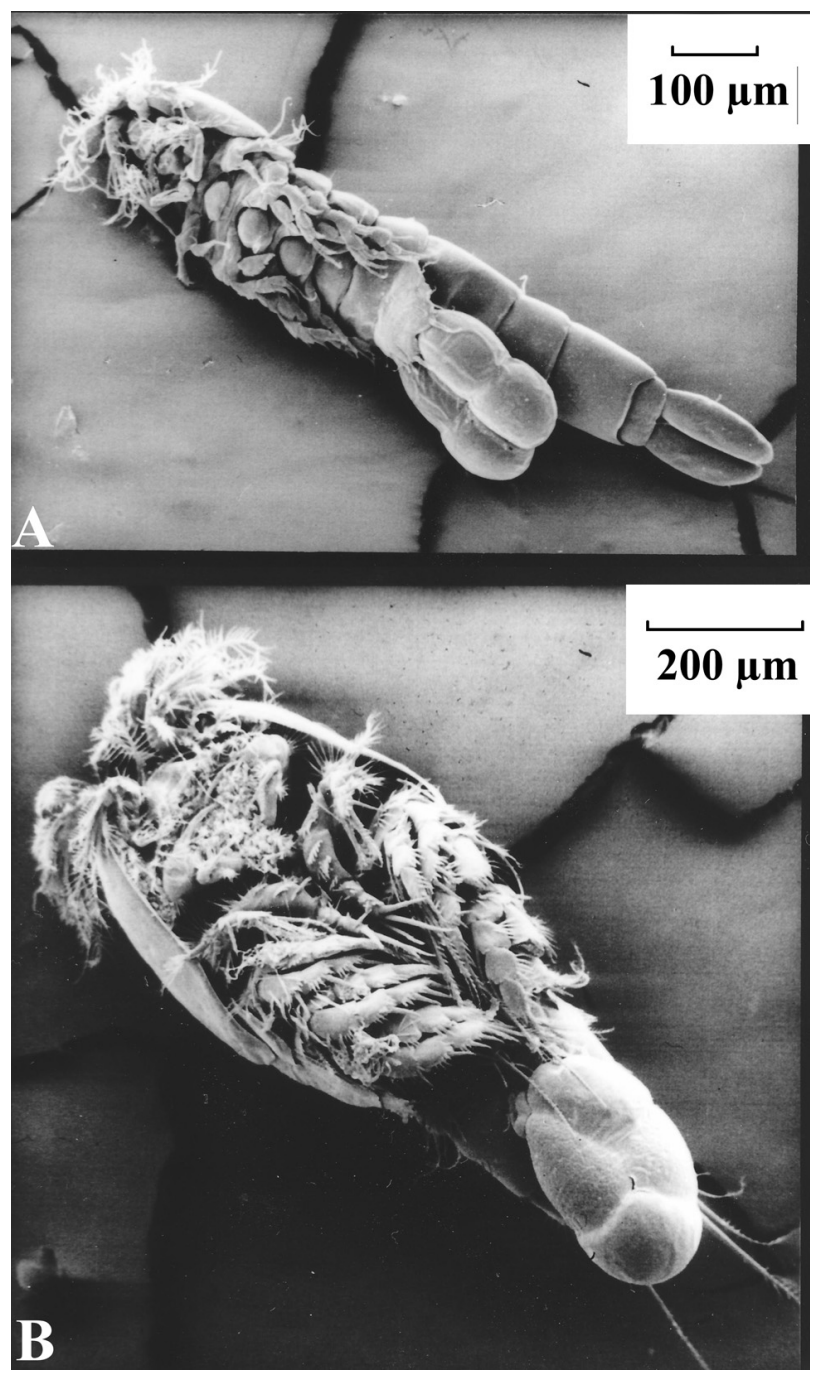

FIG. 3. - REM-photographs of adult, egg-sac carrying females (ventral views) of Copepoda Harpacticoida from Potter Cove: A. Scottopsyllus (S.) praecipuus Veit-Köhler, 2000 and B. Pseudotachidius jubanyensis Veit-Köhler and Willen, 1999.

tion. The mean body volume per copepod ranged between 3.0 and $5.0 \mathrm{nl}$ for nearly all stations, but at 1.05 the very high mean individual body volume of $11.2 \mathrm{nl}$ was detected for the few animals collected at this exceptional site, which was covered with cyanobacteria. Along a depth gradient on both tran- sects (omitting 1.05) the mean biovolume of other harpacticoids decreased (1.10: $4.8 \mathrm{nl}$ to $1.30: 3.5 \mathrm{nl}$; 2.05: $5.0 \mathrm{nl}$ to 2.30: $3.0 \mathrm{nl}$ ).

When sorted for geometrical size classes (Table 3, Fig. 2), most of the measured benthic copepods in Potter Cove belonged to size class 4 (1.6-3.19 nl). Towards the lower and the higher size classes the numbers of individuals continuously decreased.

\section{Pseudotachidius jubanyensis and Scottopsyllus (S.) praecipuus}

The two species Pseudotachidius jubanyensis and Scottopsyllus (S.) praecipuus (Fig. 3) have been described from Potter Cove (Veit-Köhler, 2000; Veit-Köhler and Willen, 1999). Their adults are the largest harpacticoids to be found at the deeper stations of the transects (Tables 4,5 ).

Adult females of the pyriform $P$. jubanyensis (conversion factor $\mathrm{C}=400$; Warwick and Gee, 1984) had an average body volume of $68.9 \mathrm{nl}$ with an average body length of $1.03 \mathrm{~mm}$. Adult males of the same species are still within size class 7 (Table 3 ), with an average body volume of $24.9 \mathrm{nl}$. Even first stage copepodids C I of $P$. jubanyensis had a biovolume that reached the average for "other" copepods from some of the transect stations. All in all, an adult female of $P$. jubanyensis increases its body volume twenty times with only five copepodid moults during its development.

Male and female adult $S$. (S.) praecipuus are represented by size classes 6 and 7. Although females of this species had about the same average body length $(0.93 \mathrm{~mm})$ as female $P$. jubanyensis, it is due to their cylindrical body shape and the resulting conversion factor $(\mathrm{C}=750)$ that they attain only about a quarter of the body volume of the other species.

Abundance-dependent classification according to size classes was not performed for $S$. (S.) praecipuus and $P$. jubanyensis. However, three markers

TABLE 4. - Body volumes of developmental stages of Pseudotachidius jubanyensis (partly distinguished for males and females) measured and calculated according to Warwick and Gee (1984). C I - C V = Copepodid I - V; C VI = Copepodid VI (adult); F = Female; M = Male.

\begin{tabular}{cccc}
\hline Pseudotachidius jubanyensis & No. Individuals measured & Mean body volume [nl] & \\
\hline C VI F & 18 & 68.9 & 24.9 \\
C VI M & 16 & 52.6 & 2.5 \\
C V F & 4 & 12.5 & 2.1 \\
C IV & 6 & 5.6 & 3 \\
C III & 7 & 3.4 & 1.3 \\
C II & 13 & 23 & 1 \\
C I & 23 & & \\
\hline
\end{tabular}


TABLE 5. - Body volumes of developmental stages of Scottopsyllus (S.) praecipuus (partly distinguished for males and females) measured and calculated according to Warwick and Gee (1984). C I - C V = Copepodid I - V; C VI = Copepodid VI (adult); F = Female; M = Male.

\begin{tabular}{cccc}
\hline Scottopsyllus (S.) praecipuus & No. Individuals measured & Mean body volume [nl] & Standard Dev. [nl] \\
\hline C VI F & 10 & 17.9 & 1.1 \\
C VI M & 12 & 11.6 & 0.7 \\
C V F & 7 & 10.9 & 1.4 \\
C V M & 8 & 9.1 & 0.7 \\
C IV F & 7 & 6.6 & 0.9 \\
C IV M & 4 & 3.4 & 0.8 \\
C III & 7 & 2.3 & 0.3 \\
C II & 11 & 1.6 & 0.3 \\
C I & 8 & & \\
\hline
\end{tabular}

TABLE 6. - Results of the Spearman rank analysis of environmental parameters versus animal data; ${ }^{1}=$ data sets for which the correlation coefficient $r_{\mathrm{S} . \mathrm{B}}$ instead of $\mathrm{r}_{\mathrm{S}}$ had to be calculated; $* *=\alpha: 0.05 ; *=\alpha: 0.1$ for the two-sided test.

\begin{tabular}{|c|c|c|c|c|c|c|}
\hline $\begin{array}{l}\text { Environmental } \\
\text { parameters }\end{array}$ & $\begin{array}{l}\text { Total number of } \\
\text { harpacticoids }\end{array}$ & $\begin{array}{l}\text { Total biovolume } \\
\text { of harpacticoids }\end{array}$ & $\begin{array}{c}\text { Number of } \\
P . \text { jubanyensis }^{1}\end{array}$ & $\begin{array}{l}\text { Biovolume of } \\
P . \text { jubanyensis }^{1}\end{array}$ & $\begin{array}{l}\text { Number of } \\
\text { S. (S.) praecipuus }{ }^{1}\end{array}$ & $\begin{array}{l}\text { Biovolume of } \\
\text { S. (S.) praecipuus }\end{array}$ \\
\hline Depth $^{1}$ & 0.330 & 0.477 & $0.827 * *$ & $0.859 * *$ & 0.704 & 0.697 \\
\hline Grain & 0.107 & -0.143 & $-0.772 *$ & $-0.726 *$ & -0.713 & -0.647 \\
\hline TOM & 0.607 & $0.786 * *$ & 0.238 & 0.294 & 0 & -0.02 \\
\hline $\mathrm{CPE}$ & 0.536 & 0.321 & -0.713 & -0.647 & $-0.772 *$ & $-0.726 *$ \\
\hline $\mathrm{C} / \mathrm{N}$ & 0.536 & 0.464 & -0.475 & -0.373 & -0.535 & -0.451 \\
\hline
\end{tabular}

for developmental stages have been placed in Figure 2 in order to highlight the exceptional positions both species hold in their environment.

As shown in Table 2, both species can only be found at the deeper stations of the two transects. While they occur at 1.20 and 1.30 , on Transect 2 they were only found at a depth of $30 \mathrm{~m}$. Their abundances in the upper $3 \mathrm{~cm}$ sediment layer are very low, with $S$. (S.) praecipuus revealing a maximum of 8 Ind. $10 \mathrm{~cm}^{-2}$ at 1.20 and $P$. jubanyensis reaching its highest abundance with 10 Ind. $10 \mathrm{~cm}^{-2}$ at 1.30 .

In order to calculate the biovolume for both species a stage-dependent approach was adopted. The data given in Table 2 are the median biovolumes found after all specimens for all sorted samples had been taken into account according to their sex and developmental stage. Despite their low densities of only a few specimens per station, both species obviously contribute to a large extent to the total biovolume at the sites where they are found. This is most strikingly apparent at 1.30: $P$. jubanyensis with only 10 individuals outranged the biovolume of 66 other copepods by over 100 $\mathrm{nl}$. The average copepod at this site had a biovolume of $3.5 \mathrm{nl}$, the average $P$. jubanyensis $34 \mathrm{nl}$.

Taking into account $P$. jubanyensis and $S$. (S.) praecipuus, the mean biovolume per copepod increased drastically at the stations where they occurred: $2.30: 4.4 \mathrm{nl}, 1.20: 5.5 \mathrm{nl}$, and at 1.30 even $7.5 \mathrm{nl}$.

\section{Statistical analyses}

Spearman rank analysis

Harpacticoid densities and biovolume along the two transects in Potter Cove can hardly be correlated with any of the environmental parameters (Table 6). Only the total biovolume of harpacticoids was correlated to the concentration of TOM at the 5\% level of significance. For $P$. jubanyensis both individual densities and biovolume were connected positively with depth at the 5\% level and negatively with grain size at the $10 \%$ level. S. (S.) praecipuus was related only to decreasing CPE-values at the $10 \%$ level. Although the main structure of the data becomes clear from the Spearman rank analysis, the CCA ordination diagram displays all at the same time.

\section{Canonical correspondence analysis}

A canonical correspondence analysis (CCA) for 6 variables (individuals and biovolume per $10 \mathrm{~cm}^{2}$ of all Harpacticoida, P. jubanyensis and $S$. (S.) praecipu$u s$ ) and 7 cases (2 transects with 3 and 4 stations respectively) was performed for the environmental data with 5 variables (depth, mean grain size, TOM, $\mathrm{C} / \mathrm{N}$ and $\mathrm{CPE}$ ). The ordination diagram of CCA displays sites and animal data as points and environmental variables as vectors (Fig. 4). The vector for depth decreases with the first axis (X), whereas CPE, 


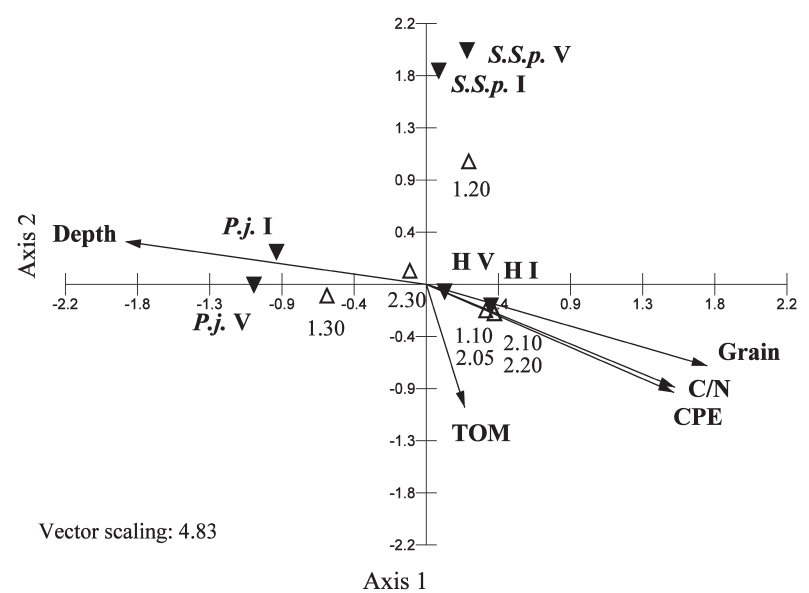

FIG. 4. - Canonical correspondence analysis of individual number (I) and biovolume (V) of Pseudotachidius jubanyensis (P.j.), Scottopsyllus (S.) praecipuus (S.S.p.) and other harpacticoids (H) (black triangles), and stations (white triangles; e.g. $2.10=$ Transect $2 ; 10$ $m$ depth) according to environmental data (vectors: depth, mean grain size (Grain), total organic matter (TOM), carbon:nitrogen ratio $(\mathrm{C} / \mathrm{N})$, chloroplastic equivalents $(\mathrm{CPE}))$.

$\mathrm{C} / \mathrm{N}$ and grain size increase with this axis. TOM is more related to axis 2 and decreases along Y. For data interpretation the vectors can virtually be produced through the axis intersection. The ordination of data points in relation to environmental vectors is determined by projecting the data points at a right angle to the corresponding vector (Ter Braak, 1987).

The deepest stations of Transect 1 and, to a far lesser extent, of Transect 2 are positively related only to depth and inversely related to the other environmental variables. 1.20 and 1.30 are found in regions with decreasing TOM and especially 1.30 is shown to contribute very low values of $\mathrm{CPE}, \mathrm{C} / \mathrm{N}$ and grain size. All remaining shallower stations $(1.10,2.05,2.10,2.20)$ are only slightly related to increasing TOM, CPE, $\mathrm{C} / \mathrm{N}$ and grain size. The same weak relation to environmental variables can be found for harpacticoid individual densities and harpacticoid biovolume. In contrast to the Spearman rank analysis in the CCA, the data point for harpacticoid individual density is higher in the order of projections onto the TOM vector than the harpacticoid biovolume.

$P$. jubanyensis and $S$. (S.) praecipuus reached their maximum abundance and biovolume at the three stations projected in quadrants I, III and IV of the diagram. $P$. jubanyensis is strongly related to depth and stations 1.30 and 2.30. It has a connection to small grain sizes as does $S$. (S.) praecipuus, which on the other hand is only to a far lesser extent related to depth. In contrast to P. jubanyensis, $S$. (S.) praecipuus can be found in relatively high abun- dance at 1.20 , which is also expressed in the CCA by the proximity of the corresponding data points. Interpreting the CCA, TOM plays a more important role for $P$. jubanyensis than for $S$. (S.) praecipuus. $\mathrm{CPE}, \mathrm{C} / \mathrm{N}$ and grain size are negatively correlated with both species. Axes 1 and 2, however, explained $96.5 \%$ of the total variance, which may be due to the relatively low number of variables.

\section{DISCUSSION}

\section{Harpacticoid densities and biovolume}

Regarding the joint plot of the CCA (Fig. 4) and the Spearman rank analysis, it becomes obvious that only the combination and consideration of both procedures can lead to a suitable interpretation. Although in a CCA environmental variables with long arrows are more strongly correlated with the ordination axes than those with short arrows, and therefore are more closely related to the pattern of variation shown in the ordination diagram (Ter Braak, 1987), the Spearman rank analysis indicates that TOM, despite the short vector, is the only environmental factor that plays a significant role concerning the biovolume of harpacticoid copepods in Potter Cove. Furthermore, this significance is not very clearly expressed in the CCA, as the data point for harpacticoid individual density is higher in the order of projections onto the TOM vector than the harpacticoid biovolume. To clarify this problem it must be taken into account that Ter Braak (1987) states that the projection of a data point onto an environmental vector indicates the position of the data point within the distribution, "although approximately".

Therefore, total harpacticoid biovolume seems to be related to food supply in terms of carbon and nitrogen availability provided by benthic and pelagic primary production. Obviously, the quality of nutrition is not as important as the total amount of organic matter, as higher individual densities can be observed at locations with a higher content of TOM, but higher $\mathrm{C} / \mathrm{N}$ ratios pointing to advanced degradation are observed at these stations as well.

In Potter Cove the highest abundance and biovolume of harpacticoids was found at 2.10 , which is situated in a depression on the ridge between the inner and outer cove. This site was at that time loaded with macroalgal detritus, as can easily be recognised from the TOM, C/N and CPE values obtained there (Table 1). Although a statement about 
temporal changes at this site cannot be made, the huge masses of macroalgal remnants indicate a regular deposition of this material at the site. Physical disturbances such as iceberg scours are known to have a negative influence on individual density and community structure of benthic macrofauna, at least initially; the duration of the recovery process is not known (Gerdes et al., 2003; Gutt and Piepenburg, 2003). For meiofauna, the recolonisation time after iceberg scouring in a shallow water habitat has been studied by Lee et al. (2001): only 30 days after the impact meiofauna abundance had reached control levels again, with copepods and ostracods being the pioneer colonisers. This might be an explanation why in Potter Cove the highest abundance of copepods was found at the most exposed site. The detritus-rich depression observed at 2.10 was probably the remnant of an iceberg scour, which served as a detritus trap in an environment characterised by strong near-bottom currents.

Mayer (2000) did an extensive survey on foraminiferans in the sediments of Potter Cove from October 1996 to December 1998. A comparison of summer data (January 1997 and 1998) from her transect with the February 1996 data from this study shows a great difference between the three transects. Her transect, which was placed between the two transects examined in this study (Fig. 1), was supposed to be more similar to Transect 1 of my study. Chloroplastic pigment content could not be checked due to different analysis procedures, but $\mathrm{C} / \mathrm{N}$ ratios along Mayer's transect were higher than those of 1.05 and 1.10 and about the same as those of 1.30 . The elevated content of dead organic material and a mean grain size of around $17 \mu \mathrm{m}$ from $5 \mathrm{~m}$ down to $30 \mathrm{~m}$ indicate that this transect differs sedimentologically from Transects 1 and 2 of this study.

Mayer's (2000) data for the uppermost $3 \mathrm{~cm}$ were added up and compared to the copepod area data of this study (Ind. $10 \mathrm{~cm}^{-2}$ from the upper $3 \mathrm{~cm}$ sediment layer). Mayer mentions foraminiferans being the most abundant meiofauna and nematodes as the most abundant metazoan taxon in the sediments of Potter Cove. However, the copepod densities from Transect 2 of this study alone nearly double the total metazoan numbers of her $20 \mathrm{~m}$ station in both years and exceed the number of metazoans from her $30 \mathrm{~m}$ station in 1998. Copepod numbers from this study always exceeded half the metazoan numbers found by Mayer, not taking into account station 1.05 for the above-mentioned reasons. These are immense differences, although all three transects are located in Potter Cove. Obviously, there must be additional factors influencing meiofaunal abundances in Potter Cove because, despite the overall high TOM content and sufficient nutrient availability, meiofauna densities along Mayer's transect were relatively low.

The comparison of four samplings from three years, in direct vicinity to each other, shows how difficult it is to compare meiofauna studies and draw the right conclusions.

De Skowronski and Corbisier (2002) studied meiofauna densities at various $15 \mathrm{~m}$ deep stations close to Potter Cove in Martel Inlet, Admiralty Bay, King George Island. Total meiofauna abundance at the Martel Inlet stations ranged between 1,953 and 6,310 Ind. $10 \mathrm{~cm}^{-2}$. With the average copepod share of about $9.5 \%$ given by them, a total amount of about 185 to 600 Ind. $10 \mathrm{~cm}^{-2}$ could be expected. The situation found in Martel Inlet is not easy to compare with the results obtained in this study, as de Skowronski and Corbisier integrated the upper 10 $\mathrm{cm}$ sediment layer. Following Mayer's findings (2000) from Potter Cove, most of the metazoan abundance was concentrated in the first $3 \mathrm{~cm}$ of sediment, although in Potter Cove she still found meiofauna metazoans at sediment depths of 10 to $16 \mathrm{~cm}$. As mean grain size at all stations of this study with a maximum of $40 \mu \mathrm{m}$ does not exceed the size of silt and clay, an interstitial life of meiofauna is not possible anywhere along the two transects. Therefore, a burrowing or epibenthic lifestyle must be assumed for all harpacticoid species (Schwinghamer, 1981; Warwick, 1984). This is particularly true for the deeper stations of the two transects, where very fluid sediments were observed. Thus, in the findings of de Skowronski and Corbisier (2002), the overall high individual numbers might be due to the mostly sandy sediments in Martel Inlet, which might provide meiofauna with more suitable interstitial habitats than they find on the Potter Cove transects. However, in this interpretation again uncertainty remains: their station with the highest individual density is a coarse silt station, which on the other hand revealed the highest organic matter content they found in Martel Inlet.

There are more reasons why comparisons with meiofauna data from other authors should be handled with care (Soyer and de Bovée, 1977). Firstly the mesh sizes used for sample treatment are different (see de Skowronski and Corbisier, 2002), and secondly the sampling methods are very diverse (corers placed by scuba divers: de 
Skowronski and Corbisier, 2002; Vanhove et al., 1998, 2000; Lee et al., 2001; sub-samples from Reineck corer: de Bovée and Soyer, 1977; Soyer and de Bovée, 1977).

An additional difficulty for data discussion is the sampled sediment volume: although individual densities are compared per $10 \mathrm{~cm}^{2}$, the sampled sediment volume due to the integration of different sediment depths varies greatly from author to author, or is not given at all (Lee et al., 2001).

Lee et al. (2001), as mentioned above, investigated copepod densities at Signy Island in temporal and spatial proximity to an iceberg scouring event. Their control samples from December 1993 and June 1994 (two replicates at each date) revealed 38 and 51.9 Ind. $10 \mathrm{~cm}^{-2}$ respectively. The highest copepod abundance within the iceberg scour region was 472 Ind. $10 \mathrm{~cm}^{-2}$ (3 months after the event), whereas the lowest was 10.1 Ind. $10 \mathrm{~cm}^{-2}$ (4 months after the event). A comparison with the data from this study is not possible, because environmental factors were not measured.

Soyer and de Bovée (1977) sampled sediments in Morbihan Bay, Kerguelen Islands, and report from depths down to $30 \mathrm{~m}$ a maximum copepod density of 259 Ind. $10 \mathrm{~cm}^{-2}$ in fine sand integrating a sediment depth of $10 \mathrm{~cm}$, although copepod numbers normally ranged between 3 and 43 Ind. $10 \mathrm{~cm}^{-}$ 2. These data are quite within the range of this study, but as the sediment was collected with a Reineck corer and subsampled, a further comparison will not be undertaken.

Again at Signy Island, Factory Cove, Vanhove et al. (1998) sampled fine sands in January and February 1994, revealing very high copepod densities of 866 and 779 Ind. $10 \mathrm{~cm}^{-2}$ respectively (calculated from $0-3 \mathrm{~cm}$ depth and the taxon-percentages given). Meiofauna in Factory Cove is provided with an excess of food during the summer $(\mathrm{C} / \mathrm{N}$ : $9-12$ for the upper three centimeters, TOM: 2 and $4 \%$ ) and copepods especially, due to highly reduced sediments, are confronted with only a few centimetres of suitable habitat. Also in Factory Cove, Vanhove et al. (2000) found correlations between harpacticoid copepods on the one hand and sediment bound pigments and organic nitrogen on the other.

Compared to Potter Cove, where even higher $\mathrm{TOM}$ and lower $\mathrm{C} / \mathrm{N}$ indicating fresher and more abundant food should support higher numbers of harpacticoid copepods, again the only plausible reason for lower harpacticoid numbers is grain size and the lack of interstitial habitat.

\section{The importance of species-related investigations}

Pseudotachidius jubanyensis and Scottopsyllus (S.) praecipuus have been described from Potter Cove (Veit-Köhler and Willen, 1999; Veit-Köhler, 2000) due to their large size and interesting reproductive strategy. Until today these species have not been reported from elsewhere in the Antarctic or adjacent regions, but the genera are widely distributed in the polar and subpolar regions. George (1999) reported Scottopsyllus from the Magellan Straits and the Patagonian continental slope. Pseudotachidius has been found in the Magellan and Beagle areas (George and Schminke, 1999) and in the Weddell Sea (Willen, 1999).

A byproduct of the studies on Pseudotachidius jubanyensis and Scottopsyllus (S.) praecipuus was that there are copepod species, which despite better food availability in shallower areas prefer the calmer, undisturbed zones of the cove, as their distribution does not seem to be related to other environmental factors (Fig. 4). The biovolume data show that only small harpacticoids with a mean individual volume of about $3 \mathrm{nl}$ seem to be adapted to the kind of environment available at these deeper sites. Adding up the total biovolume at 1.30 (Table 2), only 78 individuals have nearly the same biovolume as 216 individuals at the $10 \mathrm{~m}$ station of Transect 2 , because of the presence of $P$. jubanyensis.

Harpacticoid biovolumes have not been published for polar regions. Due to the appearance of $P$. jubanyensis and $S$. (S.) praecipuus, total biovolume increases with depth, whereas the rest of the community experiences a decrease in mean biovolume with depth.

For the future, ecological studies will have to be combined with diversity studies on species level in order to elucidate relationships that up to now are unknown or neglected, and to verify the assumption that body size in Antarctic meiofauna is an additional means of differentiating between sites.

\section{ACKNOWLEDGEMENTS}

The author would like to thank the Dirección Nacional del Antártico, Argentina, and the AlfredWegener-Institut für Polar- und Meeresforschung, Germany, for the logistic support during two Antarctic campaigns at Jubany base. Special thanks go to the author's diving companions Dr. Marcos Tatían and Dr. Ricardo Sahade (University of Cor- 
doba, Argentina), Augusto Fernández, Esteban Andrade and Oscar Rillos (Prefectura Naval Argentina), as well as Dr. Stephan Kühne and Dr. Jens Kowalke (Alfred-Wegener-Institut, Bremerhaven, Germany). The support of the Deutsche Forschungsgemeinschaft (DFG, Da-256/3-2) is gratefully acknowledged.

\section{REFERENCES}

Armada de Chile, Instituto Hidrográfico. - 1989. Atlas Hidrografico. 4 th ed.

Bouvy, M. and J. Soyer. - 1989. Benthic seasonality in an intertidal mud flat at Kerguelen Islands (Austral Ocean). The relationships between meiofaunal abundance and their potential microbial food. Polar Biol., 10: 19-27.

Bovée, F. de and J. Soyer. - 1977. Le meiobenthos des îles Kerguelen données quantitatives. I - III. CNFRA, 42: 237-265.

Folk, R.L. - 1974. Petrology of sedimentary rocks. Hemphill Publishing Company, Austin, Texas.

George, K.H. - 1999. Community analysis of the harpacticoid fauna of the Magellan region, as well as first comparisons with Antarctic associations, basing on similarity analyses. Ber. Polarforsch., 327: 187p.

George, K.H and H.K. Schminke. - 1999. Sublittoral Harpacticoida (Crustacea, Copepoda) from the Magellan Straits and the Beagle Channel (Chile). Preliminary results on abundances and generic diversity. Sci. Mar., 63(Suppl. 1): 133-137.

Gerdes, D., B. Hilbig and A. Montiel. - 2003. Impact of iceberg scouring on macrobenthic communities in the high-Antarctic Weddell Sea. Polar Biol., 26: 295-301.

Giere, O., A. Eleftheriou and D.J. Murison. - 1988. 5. Abiotic Factors. In: R.P. Higgins and H. Thiel (eds.), Introduction to the study of meiofauna, pp. 61-78. Smithsonian Institution Press, Washington.

Greiser, N. and A. Faubel. - 1988. 6. Biotic Factors. In: R.P. Higgins and $\mathrm{H}$. Thiel (eds.), Introduction to the study of meiofauna, pp. 79-114. Smithsonian Institution Press, Washington.

Gutt, J. and D. Piepenburg. - 2003. Scale-impact on diversity of Antarctic benthos caused by grounding of icebergs. Mar. Ecol. Prog. Ser., 253: 77-83.

Jensen, P. - 1982. A new meiofauna sample splitter. Ann. Zool. Fenn., 19: 233-236.

Klöser, H. and W.E. Arntz - 1994. RASCALS (Research on Antarctic Shallow Coastal and Litoral Systems). Untersuchungen zur Struktur und Dynamik eines antarktischen Küstenökosystems. Polarforsch., 64(1): 27-41.
Lee, H.J., S. Vanhove, L.S. Peck and M. Vincx. - 2001. Recolonization of meiofauna after catastrophic iceberg scouring in shallow Antarctic sediments. Polar Biol., 24: 918-925.

Mayer, M. - 2000. Ecology of benthic Foraminifera in the Potter Cove (King George Island, Antarctica). Ber. Polarforsch., 353: 1-126.

McIntyre, A.D. and R.M. Warwick. - 1984. Meiofauna techniques. In: N.A. Holme and A.D. McIntyre (eds.), Methods for the study of marine benthos, pp. 217-244. Blackwell, Oxford.

Sachs, L. - 1974. Angewandte Statistik, 4th ed., 545 p. Springer, Berlin.

Schwinghamer, P. - 1981. Characteristic size distributions of integral benthic communities. Can. J. Fish. Aquat. Sci., 38: 1255-1263.

Skowronski, R.S.P. de and T.N. Corbisier - 2002. Meiofauna distribution in Martel Inlet, King George Island (Antarctica): sediment features versus food availability. Polar Biol., 25: 126-134.

Soyer, J. and F. de Bovée. - 1977. First investigations on the density of soft bottom meiofauna in Morbihan Bay (Kerguelen Islands). In: G.A. Llano (ed.), Adaptations within Antarctic ecosystems. Proceedings of the third SCAR Symposium on Antarctic Biology, pp. 279-292. Gulf Publ. Co, Houston.

Ter Braak, C. J. F. - 1986. Canonical correspondence analysis: A new eigenvector technique for multivariate direct gradient analysis. Ecology, 67(5): 1167-1179.

Ter Braak, C. J. F. - 1987. The analysis of vegetation-environment relationships by canonical correspondence analysis. Vegetatio, 69: 69-77.

Vanhove, S., H.J. Lee, M. Beghyn, D. Van Gansbeke, S. Brockington and M. Vincx. - 1998. The metazoan meiofauna in its biogeochemical environment: the case of an Antarctic coastal sediment. J. Mar. Biol. Ass. UK, 78: 411-434.

Vanhove, S., M. Beghyn, D. Van Gansbeke, L.W. Bullough and M. Vincx. - 2000. A seasonally varying biotope at Signy Island, Antarctic: implications for meiofaunal structure. Mar. Ecol. Prog. Ser., 202: 13-25.

Veit-Köhler, G. - 2000. Habitat preference and sexual dimorphism in species of Scottopsyllus (Copepoda, Harpacticoida) with the description of Scottopsyllus (S.) praecipuus sp. n. from the Antarctic. Vie Milieu, 50(1): 1-17.

Veit-Köhler, G. and E. Willen. - 1999. Pseudotachidius jubanyensis sp. nov. (Copepoda: Harpacticoida): A new species from Antarctic shallow waters and its ecology. Senckenberg. marit., 30(1/2): 27-45.

Warwick, R.M. - 1984. Species size distributions in marine benthic communities. Oecologia, 61: 32-41.

Warwick, R.M. and J.M. Gee. - 1984. Community structure of estuarine meiobenthos. Mar. Ecol. Prog. Ser., 18: 97-111.

Wells, J.B.J. - 1986. Biogeography of benthic harpacticoid copepods of the marine littoral and continental shelf. Syllogeus, 58: 126-135.

Willen, E. - 1999. Phylogeny of the Thalestridimorpha Lang, 1944 (Crustacea, Copepoda). Cuvillier, Göttingen, 233p. 
